\title{
Senior High School Teachers Knowledge in the use of Information Communication Technology: A Survey in Asikuma-Odoben- Brakwa District
}

\author{
David Baidoo-Anu ${ }^{1 *}$ Martin Maxmillian Acquah ${ }^{2}$ Leticia Owusu Ansah ${ }^{3}$ Aaron Ato-Davis ${ }^{4}$ Vincent Narh Baah ${ }^{5}$ \\ 1. Department of Education and Psychology, University of Cape Coast, Ghana \\ 2. and 5 Department of Geography and Regional Planning University of Cape Coast \\ 3. Department of Business and Social Science Education University of Cape Coast \\ 4. Department of Education Presbyterian College of Education, Akropong \\ * E-mail of the corresponding author: baidooanu@gmail.com
}

\begin{abstract}
The purpose of the Study was to examine the use of ICT in teaching and learning among Senior High School teachers in Asikuma-Odoben-Brakwa District. The descriptive survey design was used for the study. The target population for this study consisted of all Senior High Schools in Asikuma-Odoben-Brakwa District. Simple random sampling was used to select 169 teachers from all Senior High Schools in Asikuma-Odoben-Brakwas District. A questionnaire was deemed most appropriate for the study. The study found that most of the Senior High School teachers do not have much knowledge when it comes to the use of ICT in facilitating teaching and learning. Results further shows that Senior High School teachers perceive that frequent power cut, limited expertise in computer skills, not having access to a computer at home with software installed for use and inadequate training opportunities for teachers to acquire new computer knowledge/skills for teaching are the challenges they face. Furthermore, the study revealed that male teachers are more knowledgeable in the use of ICT than the female teachers. Notwithstanding, the younger teachers are also more knowledgeable in the use of ICT than the older teachers. The study recommended that Government should organise seminars and workshop for teachers to equip them with skill and knowledge in the use of ICT to facilitate effective teaching and learning. The Government should provide more reliable access to the internet to teachers to facilitate effective teaching and learning. The head teachers of the various senior high schools should also collaborate with Past Students Associations and the Parent Teachers Association to solicit for fund to purchase computers for their school to enhance the use of ICT in teaching.
\end{abstract}

Keywords: Senior High School, Teachers, ICT , Knowledge

DOI: $10.7176 / \mathrm{JEP} / 10-21-15$

Publication date:July $31^{\text {st }} 2019$

\section{Introduction}

Globally information and communication technology (ICT) is being used for quality and efficient work practices. It appears most homes and offices make use of ICT to make work done easily. The educational sector is not spared from the attractive usefulness of ICT at work. Teaching and learning has proved positive with the use of ICT (Selwyn, 2007). In this technological age, it has become imperative that teachers move from the traditional system of chalkboard writings towards the use of ICT in teaching (Kozma, 2003). It has been observed that the use of Information and Communication Technology (ICT) is vital in ensuring quality in teaching-learning process (Goktas, Yildirim \& Yildirim, 2009). Nowadays, the actual impact of integration of ICT into everyday classroom practices constitutes an essential question. A significant amount of research has shown that the use of ICT in education can increase students' motivation and deepen understanding, promote active, collaborative and lifelong learning, offer shared working resources and better access to information, and help them to think and communicate creatively (Jonassen, 2000; Webb, 2005).

Notwithstanding, the education system in Ghana is viewed as the prime mover in the development of the country. Consequently, the education system is set to embrace the challenge to produce a society and a workforce that is equipped with the knowledge and skills to utilise new communication technologies in both contemporary and innovative ways. At present, the Ghanaian government is embarking on a "revolution in education" as part of its ongoing programme in the 2007 educational reform. The thrust of this "revolution" is a mass campaign in computer literacy whereby every school will have access to a computer. (Ministry of Education Science and Sports, 2007). 
While information and communication technology (ICT) is not a panacea for all educational problems, today's technologies are essential tools for teaching and learning. To use these tools effectively and efficiently, teachers need visions of the technologies' potential, opportunities to apply them, training and just-in time support, and time to experiment. Only then can teachers be informed and confident in their use of new technologies. As new concepts of learning evolve, teachers are expected to facilitate learning and make it meaningful to individual learners rather than just to provide knowledge and skills. Modern development of innovative technologies have provided new possibilities to teaching professions, but at the same time have placed more demands on teachers to learn how to use these new technologies in their teaching. These challenges ask teachers to continuously retrain themselves and acquire new knowledge and skills while maintaining their jobs (Carlson \& Gadio, 2002).

\section{Statement of the Problem}

In Ghana, in spite of the widespread reports of the benefits of computers in transforming teaching and independent thinking, it is often reported that a majority of teachers, especially at the Senior High School level, do not take advantage of computer access to change their teaching methods. Teachers across many regions and countries have been found to be more likely to adopt ICT for preparing class hand-outs, preparing lessons, keeping records and sending emails (which are indeed all functions that improve teacher efficiency) than they are to put computers into the hands of students for them to do independent research and class presentations (Alkahtani, 2002). Some of this might be due to difficulties that teachers experience in switching to the new teaching methods that accompany computer use. Computer use is most effective in company with collaborative teaching and learning and tends to alter the balance of power and knowledge between teachers and students, developments that might not always be welcome (Cradler et al., 2002).

Senior High Schools in Asikuma-Odoben-Brakwa District not an exception. Integrating ICT into teaching and learning has become a very serious challenge. Though the schools desire to integrate ICT into teaching and learning to facilitate teaching and learning, however, it has become very difficult for the school to do so. It is against this background that the researchers desire to investigate into the use of ICT in teaching and learning among Senior High School teachers in Asikuma-Odoben-Brakwa District.

\section{Purpose of the Study}

The purpose of the Study is to examine the use of ICT in teaching and learning among Senior High School teachers in Asikuma-Odoben-Brakwa District. However, the study will specifically seek to;

1. Identify teachers' use of ICT in teaching and learning in Senior High School Asikuma-OdobenBrakwa District.

2. Find out the perceived challenges teachers face in the use of ICT in Senior High School Asikuma-Odoben-Brakwa District.

3. Whether significant differences exist between teachers' knowledge in ICT use on the basis of gender.

4. Whether significant differences exist between teachers knowledge in ICT use on the basis of age.

\section{Research Questions}

Based on the purpose of the study, the following research questions were formulated to guide the study;

1. What are Senior High School teachers' knowledge level in the use of ICT in teaching and learning?

2. What are the perceived challenges Senior High School teachers in Asikuma-Odoben-Brakwa District faces in the use of I.C.T ?

\section{Research Hypothesis}

1. H0: There is no statistically significant difference in the teachers ICT usage level in teaching and learning on the basis of gender

H1: There is a statistically significant difference in the teachers ICT usage level in teaching and learning on the basis of gender

2. H0: There is no statistically significant difference in the teachers ICT usage level in teaching and learning on the basis of age.

H1: There is a statistically significant difference in the teachers ICT usage level in teaching and 
learning on the basis of age.

\section{Significance of the Study}

The study is very imperative as it will shed more light on the various challenges teachers face integrating I.C.T into teaching. Knowledge of this will help school authorities to take pragmatic steps to alleviate these challenges. The study will further help facilitate easy integration of I.C.T into teaching and learning thereby, enhancing effective teaching and learning. The study will also serve as a source of knowledge for further studies.

\section{LITERATURE REVIEW}

\section{ICT Skills and Competences of Teachers}

The use of ICT in higher education enhances student-centered learning. There is a growing concern that the willingness of teachers to use ICT in teaching is partly a function of the skills and competencies they possess in ICT prior to their teaching (Oliver, 2002). In this regard, Jager and Lowman (1999) maintain that it cannot be expected of young and just starting teachers to act as change agents. They have to adjust to the situation they encounter and have to familiarize themselves with the new concepts and applications. This assertion presupposes that the tutor who enters the teaching with some level of skills and competencies is likely to adopt and use this innovative change faster than someone who enters with no knowledge on ICT. Knowledge dispels misconceptions and clarifies misunderstandings; prejudice and fear then decrease Hawkins, 2002). Thus, there is the need for capacity building to improve and update the quality of the existing teaching force, and also to ensure that teacher education programmes integrate content, pedagogy, and technology (Hughes, 2005; Koehler \&Misha, 2009).

Regardless of the quantity and quality of technology available in classrooms, the key to how ICTs are used is the teacher; therefore, teachers must have the competence and the right attitude towards technology (Kadel, 2005). This is supported by Jager and Lokman(1999) who posits that a meaningful integrative ICT based education entails collaborative and collective approach involving teacher, training institutions and trainees will help teachers to learn from each other through collaborative arrangement. This obviously calls for various workshops for SHS teachers to get themselves acquainted with the use of ICT in teaching and learning; it also implies that learners should be involved in the successful use of ICT during instruction. This puts responsibility on administrators to put resources together to let this materialise. They also ensure that the success of using ICT to teach does not solely lie on the shoulders of tutors but the collective effort of teachers. This in turn calls for ICT skill training and general workshops for both tutors and teacher trainees to benefit.

Koehler and Mishra (2009) reported that many teachers had their degrees at a time when educational technology was at the beginning stage of development. Therefore, these authors stressed that "It is, thus, not surprising that they do not consider themselves sufficiently prepared to use technology in the classroom and often do not appreciate its value or relevance to teaching and learning" (Koehler \& Mishra, 2009, p. 62).In addition to this, Lee (2008) pointed out that many teachers "of advanced age" might not have had any computer education when in college, and as a result are in need of computer skills training to allow them to make use of computers in their work. Also Preston et al. (2000) argues that teachers feel they have not had adequate training, particularly in their ability to solve technical problems and in understanding the basic workings of the technology, and this in the same vein Manternach-Wigans et al. (1999) observed that teachers were often frustrated by the expectation that they learnt technology skills and applications on their own, perhaps through reading a book in order to meet up with the growing demands of using ICT in teaching. It is therefore necessary that Ghana Education service set up ICT centres where teachers in their free periods can go in to practice on their own and again the need for libraries to be stuffed with enough practical materials and books on ICT that will help tutors to read on their own for further understanding and acquire the necessary skills and competences.

Consequently, higher education institutions should face the development/improvement of pedagogical competences in ICT of the teachers as a continuous process, where the initiation to the pedagogical uses of ICT should be integrated into teacher education programs, as a dynamic and evolving process of professional development of students and in-service primary teachers. This appears to suggest that regardless of the numerous provisions of ICT equipment, it is still imperative that tutors acquire the skills needed to access and use them this is supported by Becta (2004). Manternach, Wigans et al. (1999) maintains that the provision of computers and other ICT equipment is very vital and at the heart of teachers motivation to use it to teach. The idea is that once they are available, tutors will definitely use them. Nevertheless, acquisition of skills as an important issue in the successful use of ICT was not annulled by Manternach et al (1999) and this means that acquisition of skills which leads to experiences play a key role in the successful use of ICT in teaching in the S.H.S in Ghana. 
Besides, inappropriate training styles will result in low levels of ICT use by tutors. Courses which lack pedagogical aspects are likely to be unsuccessful (Veen, 1993), but there also need to be an element of ICT skills training (Preston et al., 2000). In order to achieve high levels of teacher competence in ICT, there is a need to provide training, and perhaps unsurprisingly, there is a great deal of literature evidence to suggest that successful training is crucial if teachers are to implement ICT successfully in their teaching (Kirkwood et al., 2000). If training is inadequate or inappropriate, then tutors at the colleges of education will not be sufficiently prepared, and perhaps not sufficiently confident, to make full use of ICT in and out of the classroom.

\section{Challenges teachers face in using ICT}

As already established in Becta (2004) and Ertmer (1999), knowing the barriers to the successfully use of ICT is of great importance to the success of its use. Several studies have established certain barriers affecting the use of ICT for instruction. According to Ertmer (1999) barriers can be viewed from two angles and these are the extrinsic and the intrinsic barriers and knowing these categories solves the problems half way as it gives the right solution suitable for overcoming each barrier Ertmer (1999). Goktas, Yildirim and Yildirim (2009) posits that even though variety of action plans have been engaged to effectively integrate ICTs in educational programs, many barriers exists in practice or in practical situation. It may therefore be necessary to look at the barriers identified by Ertmer (1999).

To start with is the intrinsic barrier. According to Ertmer (1999) intrinsic barriers includes teachers' beliefs, attitudes and views about knowledge, learning and teaching. Teacher's belief as a matter of fact has a reasonable role to play in terms of teacher's willingness to use ICT in teaching. According to Ajzen and Fishbein (1980) the belief one has in putting up a behavior strongly determines whether he will put up the behavior or not. It implies that if the tutors have a strong believe in the usefulness of ICT use in teaching and believe that it has a positive influence on their teaching, the likeliness that they will access and use it is very high whilst they will abandon the use of the ICT equipment even though they are available if they build up the believe that ICT will rather interrupt their teaching and make it non interactive. The afore mentioned reason support the literature that says that the availability of ICT equipment does not guarantee that tutors will use them to teach.

The success of any initiatives to implement technology in an educational program depends strongly upon the support and attitudes of teachers involved. It has been suggested that if teachers believed or perceived proposed computer programs as fulfilling neither their own or their students' needs, they are not likely to attempt to introduce technology into their teaching and learning Veen (1993). According to Ajzen and Fishbein (1980), an individual's attitude towards the behavior affects his or her actual behavior. These important assertions call for an investigation of teacher's attitude towards the use of ICT in teaching.

The above statement presupposes that if the attitudes of tutors are the type that makes them aggressive to meet up with new challenges such as the use of ICT for instruction, then they are likely to make the best out of ICT. On the other hand, if it is that type that makes them think that ICT is difficult and too cumbersome and impossible to use then they will show a lackadaisical attitude towards it and find it boring to use, this is supported by Davis, Bagozzi and Warshaw (1989). Due to its novel presence in society and its intervention in schools in particular, ICTs may not be well received by the teachers lest it should prove to be an extra burden on them. "The mismatch between the teacher's culture of techno-centric mindedness and their pedagogic culture would often result in their alienation from the use of technology" Jung (2001 pg 36); this is also supported by Ertmer (1999).Among the factors that affect the successful use of computers in the classroom are teachers' attitudes towards computers (Albirini, 2006). Attitude, in turn, constitutes various dimensions and some examples of these are perceived usefulness, computer confidence (Cuban, 2001), training (Toure, 2009), gender (Sadik, 2006), knowledge about computers Traxler (2009), anxiety, confidence, and liking (Yildirim, 2000). It appears that attitude is broad and embraces other elements such as confidence, training, gender and anxiety.

In many developed countries, nearly all schools are equipped with the infrastructure to conduct ICT mediated teaching and learning. Positive teacher attitudes towards computing are critical if computers are to be successfully integrated into the school curriculum. A major reason for studying teachers' attitude towards computer use is that it is a major predictor for future computer use in the classroom (Smith, Caputi, \& Rawstorne, 2000). Asan (2002) studied a representative sample of pre-service teachers and found a significant relationship between computer attitude and its use in the institution.

This finding was corroborated by Yuen and Ma (2002) who, using the Chinese Computer Attitude Scale for Teachers (CAST), found that 216 secondary teachers in Hong Kong had reported the instructional use of computers and their results revealed that affective attitudes, general usefulness, behavioural control, and pedagogical use to be significant in determining the use of ICT, these findings are being supported by Ajzens (1991) 
theory of planned behaviour which notes that attitude leads to a behaviour, hence the action of tutors using ICT in teaching is partly influenced by tutors attitude towards the use of ICT equipment .

Kumar and Kumar (2003) has pointed that the amount of computer experience people have has a positive effect on their attitude towards computers, implying that if the tutors at the colleges of education have the requisite skills and knowledge in the use of ICT, they will be motivated to use them in their teaching as the knowledge of the use of ICT will build their confidence and morale in using them. Jackson, Chow, and Leitch (1997) maintains that female users, compared with males, are more inclined to hold negative reactions to computers and such differences may have resulted in the different ways of using computers. In achieving excellence in schools, it is important to ensure that teachers are able to integrate technology into the curriculum. As such, the groundwork must be laid at the trainee or pre-service teacher's level. To do otherwise is to produce future teachers with underdeveloped skills in the use of technology.

In the course of their training, pre-service teachers should be provided with the tools and experiences that will be useful for the regular activities in their future job: classroom instruction, research, and problem solving. Using technology enables pre-service teachers to arrange their environment and adjust their instructional strategies Wang (2008). On the part of teacher educators, there is a need to understand the dimensions that influence tutors attitudes towards ICT as a means for successful teaching and learning that will prepare pre-service teachers to face the challenges in the information age (Fisher, 2000). Other factors that influence teachers' decisions to use ICT in the classroom include access to resources (Gulbahar, 2005); quality of software and hardware (Mumtaz, 2000); attitude towards technology (Albirini, 2006), competence (Knezek \& Christensen, 2002); ease of use (Peralta and Albuquerque., 2007); educational beliefs (Ertmer 2005); self-efficacy beliefs; incentives to change (Granger, Morbey, Lotherington, Owston\&Wildeman, 2002); support and collegiality in their school (Hennessy 2010); school and national policies, commitment to professional learning (Jung 2003); and background in formal training (Afshari et al, 2008). Among these factors, the strength of teachers ICT skills and the attitude towards ICT as such seem to play a pivotal role in helping them make use of ICT in their teaching-learning process and in turn in proving themselves to be successful teachers and facilitators of ICT intervention and integration both of pedagogy and technology as their principal forte. However, the early studies in this field have ignored teacher attitudes toward computer (Harper, 1987). Some studies have indicated that teachers' attitudes toward ICT have significant implications for their behaviours in the use of ICT for teaching (Davis, 1989; Kellenberger \& Hendricks, 2003; Lawton \& Gerschner, 1982). During the process of combining ICT with education, teachers' attitude towards using knowledge besides their talent and desire will be a crucial point affecting the results of application. The basic agent for establishing and working this system is teachers Becta (2004). It is argued that successful integration of ICT in education enables teachers to transform instruction from teacher-centred to student-centred where learners may interact with their peers and use the computers and internet for their own learning needs. However, many teachers do not regard themselves fully-equipped, comfortable and sufficient in using ICT in educational settings, and they feel more confident with their traditional teaching styles (Hawkins, 2002).

In support of the importance of teachers' attitude towards computer use, Zhao and Frank (2003) provide evidence to suggest that the attitudes of teachers are directly related to computer use in the classroom. For example, teachers often view the computer as a tool to accomplish housekeeping tasks, manage their students more efficiently, and to communicate with parents more easily. The success of student learning with computer technology will depend largely on the attitudes of teachers, and their willingness to embrace the technology (Teo, Chai, Hung \& Lee, 2008). Gaining an appreciation of the teachers' attitudes towards computer use may provide useful insights into technology integration, its acceptance and the usage of technology in teaching and learning. Aagin, Ertmer (1999) insufficient stated technical support as part of extrinsic barriers impeding the use of ICT for teaching. Technical support as stated in Gesci (1997) includes skills training, workshops as well as in-service training organised for schools. On the contrary, it is common to find tutors enter the SHS to teach without any prior knowledge in ICT; this is supported by Yidana (1997) who.

\section{RESEARCH METHODOLOGY}

For the purpose of this study, the descriptive design was used for the study. The target population for this study consisted of all Senior High Schools in Asikuma-Odoben-Brakwas District. Simple random sampling was used to select 169 teachers from all Senior High Schools in Asikuma-Odoben-Brakwas District. A questionnaire was deemed most appropriate for the study. We pre-tested the instrument that was used. Pre-testing in the view of Donald (1990) helps the researcher to decide whether the study is feasible and worthwhile to continue and also provides an opportunity to assess the appropriateness and practicality of the data collection instrument. The 
instrument was pre-tested in order to check understanding and ambiguity and correct any misunderstandings which would be due to the framing and construction of the items. The reliability index for the questionnaire was calculated using Cronbach's alpha reliability to check for the internal consistency of the questionnaire, which gave reliability coefficients of 0.78 . On the issue of confidentiality, an effort was made to maintain confidentiality of the responses of the participants. Participants were told that their responses would be kept confidential and that no one known to them would have access to the information provided and none of the respondents names were recorded in the study.

\section{RESULTS, DISCUSSION AND CONCLUSION}

\section{Demographic Characteristics of the Respondents}

The demographic characteristics of the teachers which were considered include: gender and age. This demographic information enriched the understanding about the category of respondents who were involved in the study. The background information of the respondents which were considered in the study is presented in Table 1 .

Table 1: Distribution of Respondents Gender

\begin{tabular}{lcc}
\hline & & \\
Gender & Frequency & Percent \\
\hline Male & 113 & 66.9 \\
& 56 & 33.1 \\
\hline Female & 169 & 100.0 \\
\hline
\end{tabular}

Source: Field Survey

From Table 1, regarding the gender of the tutors who participated in the study, the data in Table 1 shows that 113 $(66.9 \%)$ were males while $56(33.1 \%)$ were females. This shows clearly that there were more male respondents than female respondents for the study.

Table 2: Age Range Distribution of Respondents

\begin{tabular}{ccc}
\hline Age Range & Frequency & Percent \\
\hline $20-30$ years & 15 & 8.9 \\
$31-40$ & 96 & 56.8 \\
$41-50$ & 58 & 34.3 \\
\hline Total & 169 & 100.0 \\
\hline
\end{tabular}

Source: Field Survey

Table 2 shows the age range distribution of the tutors who participated in the study. From the Table 2 above, it clearly indicates that $96(56.8 \%)$ were between $31-40$ years of age, $58(34.3 \%)$ were between the age range of 41 50 years. Moreover, $15(8.9 \%)$ of the respondents were between the age range of 20-30 years. This implies that majority of the respondents were between the age range 31-40years.

\section{Objective One}

The main objective of this research question was to explore the Junior High School teachers' level of knowledge in ICT. On a four-point, Likert-type scale $(1=$ strongly disagree, $2=$ disagree, $3=$ agree, and $4=$ strongly agree $)$, teachers were asked to indicate their levels of agreement or disagreement with statements posed by the researcher on the ICT knowledge level. The results were discussed using means and standard deviation. A mean of 2.50 and above indicates respondents' agreement with the factors while a mean of 2.49 and below indicates respondents' disagreement with the factors. The results are presented in Table 3. 
Table 3: Teachers Use of ICT in Teaching and Learning

\begin{tabular}{lll}
\hline & $\mathrm{N}=169$ \\
Statements & Mean & Std. Deviation \\
\hline I use word processor to facilitate teaching and learning & 1.98 & .677 \\
I am able to start and shut a computer & 3.07 & .678 \\
I make use of the internet to facilitate teaching and learning & 1.94 & .679 \\
I make use of spread sheets to enhance effective teaching and learning & 2.07 & .613 \\
I make use of excel to facilitate teaching and learning & 2.02 & .690 \\
I use email, word processing, whatapp, instagram, Facebook, etc for personal & 2.08 & .812 \\
communication and document preparation. & 2.25 & .793 \\
I use a search engine such as Google, yahoo,etc for research & 2.17 & .696 \\
I use Microsoft PowerPoint for presentation in class & 2.01 & .711 \\
I use the computer for classroom management and students' assessment/evaluation & $\mathbf{2 . 1 7}$ & $\mathbf{0 . 7 0}$ \\
Mean of Means & & $\mathbf{0 . 7 0}$
\end{tabular}

Source: Field Survey

Table 3 shows the results of the respondents' views their ICT knowledge level. It is obvious from the results that the majority of the respondents disagree with the statements concerning their use of ICT. For example, it was realized that teachers $(\mathrm{M}=1.98 ; \mathrm{SD}=.677)$ strongly disagreed with the statement that "I use word processor to facilitate teaching and learning". The results suggest that tutors do not usually use word processor in teaching and learning.

From Table 3, concerning the statement, "I am able to start and shut a computer", it was observed that the tutors $(\mathrm{M}=3.07 ; \mathrm{SD}=.678)$ strongly agreed. This result indicates that tutors have adequate knowledge on starting and shutting of computer. It was found that tutors $(\mathrm{M}=1.94 ; \mathrm{SD}=.679)$ strongly disagreed with the statement that they mostly make use of the internet to facilitate teaching and learning. This result also indicates that tutors do not make use of internet to facilitate teaching and learning. Moreover, it was revealed that tutors $(\mathrm{M}=2.07 ; \mathrm{SD}=0.613)$ disagreed with the statement that they make use of spread sheets to enhance effective teaching and learning. This result clearly shows that mostly do not make use of spread sheets to enhance effective teaching and learning. Also, from Table 3, tutors $(\mathrm{M}=2.02 ; \mathrm{SD}=.690)$ disagreed with the statement that they make use of power point presentation to facilitate teaching and learning. This result implies that tutors do not mostly make use of power point presentation to facilitate teaching and learning. Again, tutors $(\mathrm{M}=2.08 ; \mathrm{SD}=.812)$ disagreed they use email, word processing, whatapp, instagram, Facebook, etc for personal communication and document preparation. This result also clearly shows they often do not use email, word processing, whatapp, instagram, Facebook, etc for personal communication and document preparation. Also, tutors $(\mathrm{M}=2.25 ; \mathrm{SD}=.793)$ indicated that they do not the frequently use Microsoft Power Point for presentation in class. Notwithstanding, as evident in Table 3, tutors $(\mathrm{M}=2.01 ; \mathrm{SD}=.711)$ disagreed with the statement that use the computer for classroom management and students' assessment/evaluation. This result implies that tutors do not use the computer for classroom management and students' assessment/evaluation. The mean of means (2.17) indicates that the sampled tutors indicated that on the average, their use of ICT in teaching and learning is low. The average standard deviation (.70) also indicates overall homogeneity in the responses of the respondents.

These results confirm the findings of Whiten (2003) who found that there is a growing recognition that most teachers especially in developing nations lack the requisite skills in ICT which makes the use of ICT in teaching unattractive and therefore serves as a barrier to its use. The finding further confirms the work of Kirkwood (2000) who indicated that most teachers do not have the needed competencies to properly use ICT to facilitate effective teaching and learning. Koehler and Mishra (2009) say that many teachers had their degrees at a time when educational technology was at the beginning stage of development. Therefore, these authors stressed that "It is, thus, not surprising that they do not consider themselves sufficiently prepared to use technology in the classroom and often do not appreciate its value or relevance to teaching and learning" (Koehler \& Mishra, 2009).

Again, Preston (2000) argues that teachers feel they have not had adequate training, particularly in their ability to solve technical problems and in understanding the basic workings of the technology, and this in the same vein Manternach-Wigans (1999) observed that teachers were often frustrated by the expectation that they learnt technology skills and applications on their own, perhaps through reading a book in order to meet up with the growing demands of using ICT in teaching. It is therefore necessary that colleges set up ICT centres where tutors in their free periods can go in to practice on their own and again the need for libraries to be stuffed with enough 
practical materials and books on ICT that will help tutors to read on their own. According to Lee (1997) a great number of students in teacher preparation programmes are not equipped with basic computer operational skills; this is supported by Ozoemelem (2010) who acknowledges that there is a low level of skilfulness in the use of ICT among teachers.

\section{Objective Two}

The main objective of this research question was to explore the challenges teachers' faces in the use of ICT. On a four-point, Likert-type scale $(1=$ strongly disagree, $2=$ disagree, $3=$ agree, and $4=$ strongly agree $)$, tutors were asked to indicate their levels of agreement or disagreement with statements posed by the researcher on the challenges tutors faces in the use of ICT. The results were discussed using means and standard deviation. $A$ mean of 2.50 and above indicates respondents' agreement with the factors while a mean of 2.49 and below indicates respondents' disagreement with the factors. The results are presented in Table 4

Table 4: The Perceived challenges teachers faces in the use of ICT

\begin{tabular}{|c|c|c|}
\hline Statements & $\begin{array}{l}\mathrm{N}=169 \\
\text { Mean }\end{array}$ & Std. Deviation \\
\hline $\begin{array}{l}\text { The frequent changes in technology make it hard to keep abreast with instructional } \\
\text { technologies. }\end{array}$ & 3.51 & .536 \\
\hline Using technology for instruction is too expensive for the Ghanaian situation. & 3.15 & .512 \\
\hline $\begin{array}{l}\text { I feel already over-burdened without adding technology professional development } \\
\text { workshops. }\end{array}$ & 3.22 & .659 \\
\hline The computers at the college are not connected to the internet & 3.22 & .722 \\
\hline Lack of motivation for using ICT in teaching affect how we use it. & 3.21 & .709 \\
\hline $\begin{array}{l}\text { There are too few training opportunities for College to acquire new computer } \\
\text { knowledge/skills for teaching. }\end{array}$ & 3.38 & 699 \\
\hline Low confidence in using ICT for teaching really affect the interest to use it & 3.10 & .642 \\
\hline $\begin{array}{l}\text { I don't have access to a computer at home with software installed for use in my } \\
\text { teaching preparation. }\end{array}$ & 3.29 & .658 \\
\hline $\begin{array}{l}\text { I don't feel confident in using computer to teach because } \\
\text { I have not much experience in using ICT to teach }\end{array}$ & 3.31 & .683 \\
\hline I have insufficient time to develop instructional materials that use computers. & 3.44 & .688 \\
\hline Power cut makes ICT use unreliable and boring & 3.55 & .499 \\
\hline $\begin{array}{l}\text { My limited expertise in computer skills prevents me from using instructional } \\
\text { technology. }\end{array}$ & 3.47 & .513 \\
\hline $\begin{array}{l}\text { Mean of Means } \\
\text { Mean of Standard deviations }\end{array}$ & 3.32 & 0.62 \\
\hline
\end{tabular}

Source: Field Survey

Table 4 shows the results of the tutors concerning the challenges they face in the use of ICT. It is obvious from the results that the majority of the respondents agree with the statements concerning the challenges tutors face in ICT use. For example, it was realized that tutors $(\mathrm{M}=3.51 \quad ; \mathrm{SD}=.536)$ strongly agreed with the statement that "The frequent changes in technology make it hard to keep abreast with instructional technologies". The results suggest that frequent changes in technology make it difficult for the teachers to keep themselves abreast with instructional technologies.

From Table 4, concerning the statement, "Using technology for instruction is too expensive for the Ghanaian situation", it was observed that the tutors $(\mathrm{M}=3.15 ; \mathrm{SD}=.512)$ strongly agreed. This result indicates that using technology for instruction is too expensive for the Ghanaian situation. It was found that tutors $(\mathrm{M}=3.22$; $\mathrm{SD}=.722$ ) strongly agreed with the statement that the computers at the college are not connected to the internet. This result also indicates that tutors computers at the college are not connected to the internet. Moreover, it was revealed that tutors $(\mathrm{M}=3.21 ; \mathrm{SD}=.709)$ agreed with the statement that the lack of motivation for using ICT in teaching affect how they use it. This result clearly shows that tutors perceive the lack of motivation for using ICT in teaching affects how they use it. Also, from Table 4, tutors $(\mathrm{M}=.3 .38 ; \mathrm{SD}=.699)$ agreed with the statement that there are too few training opportunities for school to acquire new computer knowledge/skills for teaching. This result implies that tutors perceive that there are too few training opportunities for College to acquire new computer knowledge/skills for teaching. Again, tutors $(M=3.29 ; \mathrm{SD}=.658)$ agreed that they don't have access to a computer at home with software installed for use in teaching. This result also clearly shows most tutors do not have their own personal computer at home. Also, tutors $(\mathrm{M}=3.55 ; \mathrm{SD}=.499)$ indicated that power cut makes ICT use unreliable and boring. Notwithstanding, as obvious in Table 9, tutors $(\mathrm{M}=3.47 ; \mathrm{SD}=.513)$ agreed with the statement 
that limited expertise in computer skills prevents them from using instructional technology. This result implies limited expertise in computer skill is challenge tutors face in using ICT.

The mean of means (3.32) indicates that the sampled tutors perceive that on the average, the above challenges in Table 4 affect their use of ICT to facilitate teaching and learning. The average standard deviation (0.62) also indicates overall homogeneity in the responses of the respondents.

This findings support the work of Davis, Bagozzi, Warshaw, (1989) who found that that ICT use is difficult and too cumbersome and impossible to use then they will show a lackadaisical attitude towards it and find it boring to use. Due to its novel presence in society and its intervention in schools in particular, ICTs may not be well received by the teachers lest it should prove to be an extra burden on them. In Ertmer (1999) also spells out those factors which affect teacher's enthusiasm to use ICT in teaching. What he mentioned includes lack of resources, insufficient technical support, lack of time and inadequate training. To begin with, lack of ICT resources is undoubtedly a major factor hacking the use of ICT in teaching. White (2003) also found that there is a growing recognition that most teachers especially in developing nations lack the requisite skills in ICT which makes the use of ICT in teaching unattractive and therefore serves as a barrier to its use, in the same vein Koehler and Mishra (2009) say that many teachers had their degrees at a time when educational technology was at the beginning stage of development. Therefore, these authors stressed that "It is, thus, not surprising that they do not consider themselves sufficiently prepared to use technology in the classroom and often do not appreciate its value or relevance to teaching and learning. Thus, there is the need for capacity building to improve and update the quality of the existing teaching force, and also to ensure that teacher education programs integrate content, pedagogy, and technology (Hughes, 2005; Koehler \& Misha, 2009).

\section{Results from Research Hypotheses}

This section, presents the analysis of the hypothesis.

Research Hypothesis One; $\mathrm{H}_{0}$ : There is no statistically significant difference in the tutors ICT usage level in teaching and learning on the basis of gender.

we sought to find out the statistically significant difference exist in tutors ICT usage of ICT in teaching and learning on the basis of gender. To achieve this, independent sample t-test was deemed appropriate. The results are presented as below.

Table 5: Result of t-test Analysis of the tutors ICT usage level in teaching and

learning on the basis of gender

\begin{tabular}{lcccccc}
\hline Gender & $\mathrm{N}$ & Mean & Std. D & Df & t-value & Sig \\
\hline Male & 133 & 20.5179 & 4.11023 & 167 & $-4.248^{*}$ & .000 \\
Female & 56 & 17.6372 & 4.22973 & & \\
\multicolumn{2}{l}{ Source: Field Survey } & & & & \\
\hline
\end{tabular}

Table 5 presents result of t-test analysis comparing the tutors ICT usage level on the basis of gender. From the Table 5, the t- test is significant at 0.05 level of significance. I therefore reject the null hypothesis which stated, that "There is no statistically significant difference in the tutors ICT usage level in teaching and learning on the basis of gender" $t(167)=-4.248^{*}, \operatorname{sig}=0.000, \mathrm{p}<.05$. Therefore, the alternate hypothesis that "There is a statistically significant difference in the tutors ICT usage level in teaching and learning on the basis of gender" was upheld. This therefore implies that there is a statistically significant difference between males and females tutors with respect to their ICT use. It is evident from the means that male tutors $(\mathrm{M}=20.5179, \mathrm{SD}=4.11023)$ use ICT in teaching and learning more than the female tutors $(M=17.6372 ; S D=4.22973)$.

The findings support the work of Oliver's (1993) who pointed out that male student and teachers are more competent in the use of ICT than their female counterpart on the other hand. This is was supported by Rajagopal and Bojin (2003) who argued that although female teachers and students appear to appreciate the use of ICT equally for pedagogy, male students and teachers appear to be more aggressive and thus easily acquire a higher and faster competent level than their female counterpart.

Research Hypothesis Two: $\mathrm{H}_{0}$ : There is a statistically significant difference in the tutors ICT usage level in teaching and learning on the basis of age 
I sought to find out the statistically significant difference exist in tutors ICT knowledge and competence level on the basis of age. To achieve this, one-way Analysis of Variance (ANOVA) was conducted to determine the differences in tutors ICT usage level on the basis of age.

Prior to conducting the One-way ANOVA, assumptions were checked. These assumptions were normality and linearity and homogeneity of variance.

Table 6: Test of Homogeneity of Variances

\begin{tabular}{llll} 
Levene Statistic & df1 & df2 & Sig. \\
\hline 17.413 & 2 & 166 & .000 \\
\hline Source: Field Survey & & \multicolumn{2}{c}{$*$ Significant, $\mathrm{p}<.05$ (2-tailed) }
\end{tabular}

From Table 6, the Significance value (Sig) for Levene' test is 0.000 which is less than the alpha or critical value of $\mathrm{p}=0.05$ shows that the assumption of homogeneity has been violated for this sample that is $[F(2,166)=$ $17.413, p=.000$ at the .05 alpha level].

Table 7: Descriptive Statistics of Teachers Age

\begin{tabular}{llll}
\hline Age Range & N & Mean & Standard deviation \\
\hline 20-30years & 15 & 25.3333 & 4.18614 \\
$\mathbf{3 1 - 4 0}$ & 96 & 18.6771 & 4.46388 \\
$\mathbf{4 1 - 5 0}$ & 58 & 16.7069 & 1.67551
\end{tabular}

From Table 7, the results show that there are differences in the mean scores. The table indicated the age of 20-30 years had the highest mean score followed by 31-40 years while, 41-50 years had the least mean score.

Table 8 - ANOVA results Comparing Teachers' Knowledge on the basis of Age

\begin{tabular}{|c|c|c|c|c|c|}
\hline & $\begin{array}{l}\text { Sum } \\
\text { Squares }\end{array}$ & Df & Mean Square & $\mathrm{F}$ & Sig. \\
\hline Between Groups & 888.488 & 2 & 444.244 & 32.086 & .000 \\
\hline Within Groups & 2298.340 & 166 & 13.845 & & \\
\hline Total & 3186.828 & 168 & & & \\
\hline
\end{tabular}

From the one-way ANOVA, $\underline{F}(2,166)=32.086$, Sig. $=.000, \underline{p} .<0.05$. From the one-way ANOVA Table 8 , the Sig. value of .000 is less than the $p$. value of $0.05(\underline{p}<0.05)$ this means that there are significant differences between means of the ages. Since the variances are assumed equal, a follow-up test or a Post Hoc test was conducted using Games Howel to find out which pairs of means are statistically different. Table 9 presents the analysis of the post-hoc. 
Table 9: Multiple Comparisons results Comparing Tutors' usage level on the basis of Age

\begin{tabular}{|c|c|c|c|c|c|}
\hline \multicolumn{6}{|c|}{ (I) Age } \\
\hline & & $(\mathrm{J})$ Age & Mean Difference (I-J) & Mean & Sig. \\
\hline \multirow[t]{6}{*}{ Games Howell } & 20-30years & $31-40$ & 6.65625 & 25.3333 & .000 \\
\hline & & $41-50$ & 8.62644 & & .000 \\
\hline & $31-40$ & 20-30years & -6.65625 & 18.6771 & .000 \\
\hline & & $41-50$ & 1.97019 & & .000 \\
\hline & $41-50$ & 20-30years & -8.62644 & 16.7069 & .000 \\
\hline & & $31-40$ & -1.97019 & & .000 \\
\hline
\end{tabular}

Post hoc comparisons using Games Howell procedure were to determine which pairs of the three group mean differed. The Games Howell was used because equal variance was not assumed, thus the assumption of equal variance has been violated. These results are given in Table 9 which indicate statistically significant difference $(\mathrm{sig}=0.000)$ teachers who are 20-30 years old and 31-40 years old. From the descriptive table teachers who are 20-30 years old $(\mathrm{M}=25.3333, \mathrm{SD}=4.18614)$ uses $\mathrm{ICT}$ in teaching and learning more than teachers who are 31-40 years old $(\mathrm{M}=18.6771 ; \mathrm{SD}=4.46388)$. Also the Table indicate statistically significant difference $(\mathrm{sig}=0.000) \mathrm{in}$ teachers who are 20-30 years old $(\mathrm{M}=25.3333, \mathrm{SD}=4.18614)$ and $41-50$ years old. From the descriptive table teachers who are 20-30 years old $(\mathrm{M}=25.3333, \mathrm{SD}=4.18614)$ uses ICT in teaching and learning more than 41-50 years old $(\mathrm{M}=16.7069, \mathrm{SD}=1.67551)$. Moreover, from Table 9, the result shows that there is a statistically significant difference $(\mathrm{sig}=0.000)$ in teachers who are $31-40$ years old and 41-50 years old. The descriptive table shows that teachers who are 31-40 years old $(\mathrm{M}=18.6771 ; \mathrm{SD}=4.46388)$ uses ICT in teaching and learning more than 41-50 years old $(\mathrm{M}=16.7069, \mathrm{SD}=1.67551)$.

This support the work of Lee (2008) who pointed out that many teachers "of advanced age" do not have had any computer education when in school, and as a result are in need of computer skills training to allow them to make use of computers in their work. Afshari, Abu Bakar, Abu Samah,and Fooi, (2008) demonstrated that as the age of the teachers decreased, their attitudes towards ICT increased. This finding confirms the results of Roberts, Hutchinson and Little's (2003) whose study predicted that the probability that teachers would use ICT in the classroom was limited by the reality that teachers who were educated 20 years ago were trained by people who themselves were trained before the arrival of computers in schools, this observations clearly indicate that young tutors in the colleges will love to use ICT to teach much more and better than their old colleagues in the same college.

\section{CONCLUSION}

From the findings, it is concluded that most of the Senior High School teachers do not have high knowledge and skills when it come to the use of ICT to facilitate teaching and learning. Results further shows that tutors (MM=3.32; $\mathrm{MSD}=0.62$ ) Senior High School teachers perceive that frequent power cut, limited expertise in computer skills, not having much experience in using ICT to teach, not having access to a computer at home with software installed for use and inadequate training opportunities for teachers to acquire new computer knowledge/skills for teaching are the challenges they face in using ICT. However, the male teachers are more knowledgeable and competent in the use of ICT than the female teachers. Notwithstanding, the younger teachers are also more knowledgeable in the use of ICT than the older tutors. This is because most of the "advanced age" might not have had any computer education when in school, and as a result are in need of computer skills training to allow them to make use of computers in their work.

\section{RECOMMENDATION}

Based on the findings and conclusions drawn from the study, the following recommendations have been made for policy and practice. The Government should organise seminars and workshop for teachers to equip them with skill 
and knowledge in the use of ICT to facilitate effective teaching and learning. The Government should provide more reliable access to the internet to teachers facilitate effective teaching and learning. The head teachers of the various Senior High Schools should also make sure that they collaborate with the various Past Students Association and the Parents and Teachers Association (PTA) to solicit for funds to purchase enough computers for their school. This will help facilitate the use of ICT in teaching and learning. The head teachers of the various high schools should encourage their older tutors and female tutors to abreast themselves with the current trends in ICT and enhance their use of ICT in teaching. The Government should provide free laptops with the necessary soft wares installed on it to aid effective use of ICT in teaching and learning.

\section{References}

Abudu, A. M., \& Fuseini, M. N. (2013). Influence of single parenting on students' academic achievement Afshari, M., Abu Bakar, K., Luan, W. S., Abu Samah, B., \& Fooi, F. S. (2008). School leadership and information communication technology. The Turkish Online Journal of Educational Technology - Tojet, 7(4).

Ajzen, I. (2010) "The Theory of Planned Behavior" Retrieved on $10^{\text {th }}$ October, 2013 from http://www.people.umass.edu/aizen/tpb.html.

Ajzen, I., \& M. Fishbein (1980) Understanding Attitudes and Predicting Social Behavior. $\quad$ Englewood Cliffs, NJ: Prentice-Hall, Inc.

Albirini, A. (2006).Teachers' Attitudes toward Information and Communication Technologies. Journal of Computer \& Education, 47, 373-398.

Alkahtani, A. (2017). The challenges facing the integration of ICT in teaching in Saudi secondary schools. International Journal of Education and Development using ICT, $13 \quad$ (1).

Asan, A. (2002). Preservice teacher's use of technology to create instructional materials: A school-college partnership. Journal of information Technology for Teacher Education 11(2), 217-232.

Becta, (2004). Harnessing Technology Review 2008: The role of technology and its impact on education, BEC1-15587. Retrieved on August 16, 2013 from: http://publications.becta.org.uk/display.cfm?resID=38751\&page=1835.

Cradler, J., McNabb, M., Freeman, M., \& Burchett, R. (2002). How does technology influence student learning? Learning and Leading with Technology, 29 (8), 46-49.

Cuban, L. (2001). Why are most teachers' infrequent and restrained users of computers in their classroom? In J. Woodward \& L. Cuban (Eds.), Technology curriculum and professional development, $\quad$ (pp. 121-137). Thousand Oaks, CA: Corwin Press.

Davis, F. (1989). Perceived Usefulness, Perceived Ease of Use, and User Acceptance of Information Technology. MIS Quarterly, 13(3): 319-340.

Ertmer, P. A., Lehman, J., Park, S. H., Cramer, J. \& Grove, K. (2003). Barriers to teachers' adoption and use of technology in the problem-based learning. In Proceedings of Association for the Advancement of Computing in Education (AACE) Society for Information Technology and Teacher Education (SITE) International Conference, Honolulu, Hawaii. Washington DC: AACE.

Ertmer, P.E.A. (1999). Examining teachers' beliefs about the role of technology in the elementary classroom. Journal of Research on Computing in Education, 32 (1), 54-72.

Gesci, A. (2007). Global e-schools and communities initiatives. Infrastructure and connectivity 4 45(10). 65-80.

Goktas, Y., Yildirim, S., \& Yildirim, Z. (2009). Main Barriers and Possible Enablers of ICTs Integration into Preservice Teacher Education Programs. Educational Technology \& $\quad$ Society, 12 (1), 193-204.

Goktas, Y., Yildirim, S., \& Yildirim, Z. (2009). Main barriers and possible enablers of ICTs integration into preservice teacher education programs. Journal of Educational Technology \& Society, 12(1).

Granger, C.A., Morbey, M.L., Lotherington, H., Owston, R.D. \& Wideman, H.H. (2002) Factors Contributing to Teachers' Successful Implementation of IT. Journal of Computer Assisted Learning, 18, 480-488.

Granger, C.A., Morbey, M.L., Lotherington, H., Owston, R.D. \& Wideman, H.H. (2002). Factors Contributing to Teachers' Successful Implementation of IT. Journal of Computer Assisted Learning, 18, 480-488.

Gulbahar, Y. (2008). ICT Usage in Higher Education: A Case Study on Preservice Teachers and Instructors. The Turkish Online Journal of Educational Technology. 7(1).

Hawkins, R. J. (2002). Ten lessons for ICT and education in the developing world. In G.

Kirkman, P. K. Cornelius, J. D. Sachs \& K. Schwab (Eds.), Global Information Technology Report 2001-2002: Readiness for the Networked World (pp. 38-44). New York: Oxford University Press.

Hennessy, S. 2010. “Teacher Factors Influencing Classroom Use of ICT in Sub-Saharan Africa.” Itupale Online Journal of African Studies 2: 39-54. 
Hughes, M. M. (2005). Reach to teach ICT: Issues and compromises. Education and Information Tech-nologies, 10(3), 263-276.

Jackson, C.M., Chow, S., \& Leitch, R.A. (1997).Towards understanding of the behavioral information system, Decision Science, 28(2), 357-389.

Jager,A K \& Lokman A. H. (1999). Impacts of ICT in Education. The Role of the Teacher and European Conference on Educational Research, Lahti, Finland

Jonassen, D. H. (2000). Computers as mindtools for schools: Engaging critical thinking. Prentice

Jonassen, D.H. \& Reeves, T.C. (1996). Learning with technology: Using computers as cognitive tools. In D.H. Jonassen (Ed.), Handbook of research on educational communications and technology. New York: Macmillan

Jung, I. S. (2001). Singapore's approach to preparing new teachers to use technology in the classroom. In J. Capper (Ed.), Case studies of innovations in teacher training and technology. Washington, DC: The World.

Jung, I. S. (2003). A comparative study on the cost-effectiveness of three approaches to ICT teacher training. Journal of Korean Association of Educational Information and Broadcasting, 9(2), 39-70.

Kadel, R. (2005). How teacher attitudes affect technology. Learning and Leading with Technology, 39 (5), 34-47.

Ellenberger, D., and S. Hendricks. (2003). Predicting teachers' computer use for own needs, teaching, and student learning. Paper presented at Hawaii International Conference on Education.

Kirkwood, M. (2000). Infusing higher-order thinking and learning to learn into content instruction: A case study of secondary computing studies in Scotland. Journal of Curriculum Studies 32(2), 509-535.

Kirkwood, M. (2000). Infusing higher-order thinking and learning to learn into content instruction: A case study of secondary computing studies in Scotland. Journal of Curriculum Studies 32(2), 509-535.

Knezek, G. \& Christensen, R. (2002). Impact of New Information Technologies on Teachers and Students. Education and Information Technologies, 7(4), 369-376.

Koehler, M. J., \& Mishra, P. (2009). What is technological pedagogical content knowledge? Contemporary Issues in Technology and Teacher Education, 9(1).60-75

Kozma, R. B. (2003). Technology and classroom practices: An international study. Journal of research on technology in education, 36(1), 1-14.

Kumar, P., \& Kumar A. (2003).Effect of a web-based project on preservice and in-service teachers' attitudes toward computers and technology skills. Journal of Computing in Teacher Education, 19(3), 87-92.

Lawton, J., \& Gerschner, V. T. (1982). A review of the Literature on Attitudes towards Computers and Computerized Instruction. Journal of Research and Development in Education, 16(1), 50-55.

Lee, J. (2008). Toward democracy: Social studies and TPCK. In Technolog (Ed.)

Manternach-Wigans, (1999). Technology integration in Iowa high schools: perceptions of $\quad$ teachers and students. Iowa State: College of Education, Iowa State University.

Ministry of Education, Science and Sports. (2006-2007). Report on the Education Sector Annual Review (ESAR). Retrieved on August $\quad 25$ th $\quad 2014$ from http://planipolis.iiep.unesco.org/upload/Ghana/Ghana_ESAR_2006_Report_Final.pdf

Mumtaz, S. (2000). Factors Affecting Teachers' Use of Information and Communications $\quad$ Technology: A review of the Literature. Journal of Information Technology for Teacher $\quad$ Education, 9(3), 319-342

Oliver, R. (1993). A comparison of students' information technology skills in 1985 and 1991. British Journal of Educational Technology, 24(1), 52-62.

Oliver, R. (2002). The role of ICT in higher education for the 21st century: ICT as a change agent $\quad$ for education. Retrieved April, 14, 2007.

Ozoemelem, O. A. (2010). Web affinity: A study of undergraduate students in Nigerian universities. Li-brary Philosophy and Practice [e-journal]. Retrieved on 15th April $2016 \quad$ from http://www.webpages.uidaho.edu/ mbolin/obuh2.htm

Peralta, H \& Albuquerque Costa, F. (2007). Teacher's Competence and Confidence regarding Educational Sciences Journal, 3(7), 67-87.

Preston, C., Cox, M.J., \& Cox, K.M,(2000). Teachers as Innovators: An Evaluation of the use information and communication technologies. Croydon, London: Mirandanet

Rajagopal, I., \& Bojin, N. (2003). A gendered world: Students and instructional technologies.

Roblyer, M.D., Edwards, J. \& Havriluk, M.A. (2004). Integrating educational technology into Saddle River, NJ: Prentice Hall.

Sadik, A. (2006) Factors Influencing Teachers' Attitudes toward Personal use and school Use of Computers New Evidence From A Developing Nation, Evaluation Review, 30(1), 86-113

Selwyn, N. (2007). The use of computer technology in university teaching and learning: a critical perspective. Journal of computer assisted learning, 23(2), 83-94. 
Smith B., Caputi P., \& Rawstorne P. (2000) Differentiating computer experience and attitudes empirical investigation. Computers in Human Behavior 16, 59-81.

Teo, T., Chai, C.S., Hung, D. \& Lee, C.B. (2008). Beliefs about teaching and uses of technology among pre- service teachers. Asia Pacific Journal of Teacher Education, 36(2), 165-176.

Toure, K. (2009). Appropriating technologies and making them work for you in teaching and learning: depth is essential. In T. Karsenti (Ed.), Pedagogical Use of ICT: Teaching and Reflecting Strategies. Ottawa: IDRC.

Traxler, J. (2009). The Learning guru and the eLearning Africa debate. Retrieved December $18^{\text {th }}, 2016 \quad$ from http://www.elearning africa.com/newsportal/english/news190.php

Veen, W. (1993). How Teachers Use Computers in Instructional Practice: four case studies in a Dutch secondary school, Computers and Education, 21(12), 1-8.

Wang, Q. (2008). A generic model for guiding the integration of ICT into teaching and learning. Innovations in Education and Teaching International, 45 (4).411-419

Webb, M. (2005). Affordances of ICT in science learning: implications for an integrated pedagogy. International Journal of Science Education, 27(6).705-735.

White, G. (2003). E-learning: Key Australian initiatives (An opportunity for all learners). Retrieved on 15th April 2016 from http://www.educationau.edu.au/papers/elearning_polaand03.pdf

Yildirim, S. (2000). Effects of an educational computing course on pre-service and in-service teachers: A discussion and analysis of attitudes and use. Journal of Research on computing in Education, 3, 479-495

Yuen, A., Ma, W. (2002). Gender differences in teacher computer acceptance. Journal of Technology and Teacher Education, $10(3), 365-382$

Zhao, Y., \& Frank, K. A. (2003). Factors affecting technology uses in schools. New York: $\quad$ Prentice Hall 